Fecha de recepción: 09-10-2017

Fecha de aceptación: 27-01-2018

Link para este artículo: http://dx.doi.org/10.14198/ALEUA.2018.29-30.01

Puede citar este artículo como:

SANTIAGO Romero, Sergio, «En el origen del TEU: a propósito de una representación unamuniana de 1940

(El otro)», Anales de Literatura Española, n. ${ }^{\circ}$ 29-30 (2018), pp. 47-63.

\title{
EN EL ORIGEN DEL TEU: A PROPÓSITO DE UNA REPRESENTACIÓN UNAMUNIANA DE 1940 (EL OTRO)
}

\author{
SERGio SANTIAGO ROMERO \\ Universidad Complutense de Madrid-ITEM
}

\section{Resumen}

Nuestro trabajo explora los tres primeros años del Teatro Español Universitario (19391941) a partir de una representación de El otro, de Miguel de Unamuno, en febrero de 1940. A partir de las contradicciones que encontramos en los datos de que disponemos actualmente, se han planteado dos hipótesis de trabajo aún por confirmar: que el TEU nacional tuviera un director anterior a Modesto Higueras, considerado hasta la fecha como su auspiciador, o que se llevaran a cabo dos funciones inaugurales del TEU de Higueras a causa del fracaso de la representación de El otro. Completaremos esta revisión historiográfica con un somero repaso de la recepción del teatro unamuniano entre los intelectuales falangistas que nos permita entender la relectura partidista que los dirigentes del SEU pudieron realizar a partir del texto de Unamuno.

Palabras clave: Unamuno, El otro, Modesto Higueras, Delegación Nacional del TEU

\begin{abstract}
Our research examines the first three years of the Spanish University Theater (19391941) on the basis of a performance of El otro, by Miguel de Unamuno, which took place on February 1940. According to the contradictions that we have found in the current existing data, we will suggest two hypotheses about TEU's origins. On the one hand, it is possible that there was a former director who was replaced by Modesto Higueras - who is considered to be the first one- . On the other hand, and because of El otro's failure, it is also possible that there were two different opening plays for the National TEU. We are completing this historiographical review with a brief summary about the reception of Unamuno's theater among the Spanish falangist leaders of the SEU. These considerations Will help us to understand their biased interpretation of Unamuno's text.
\end{abstract}

Keywords: Unamuno, El otro, Modesto Higueras, TEU's National Local Office

Anales, 29-30 (2018), pp. 47-63

DOI: 10.14198/ALEUA.2018.29-30.01 
Nuestro estudio parte de un hecho que, aislado, podría parecer trivial en el estudio general del Teatro Español Universitario: una representación universitaria de El otro, tragedia de Unamuno, en febrero de 1940. ${ }^{1}$ Sin embargo, al contextualizar este montaje concreto dentro del panorama de los años cuarenta, veremos que se trata de una representación clave para entender y reformular los orígenes del TEU. Nos ocuparemos, primero, de los datos que tenemos de esta representación fantasma de El otro, llevada a cabo en el Teatro Español de Madrid a principios del año 1940 a cargo de «la Delegación Nacional del Teatro Español Universitario (SEU)». Que se mencione la participación de dicha delegación nacional en la producción resulta de especial trascendencia, porque hasta la fecha la bibliografía solía ubicar los orígenes del TEU Nacional a principios de 1941. Quienes se han dedicado al TEU hasta la fecha han constatado ya los oscuros orígenes de esta Delegación Nacional, que se pierden y entremezclan con la existencia previa de grupúsculos de teatro universitario con actividad acreditada desde los años de la Guerra Civil. Quizás por la dificultad de realizar afirmaciones con apoyo documental exacto, los historiadores del TEU se limitaron a señalar que es la década de los años cuarenta cuando comenzó la andadura de los TEUs [Oliva, 1999: 16; Pérez-Rasilla, 1999: 32-33]. Solo la biografía-homenaje que Manuel Gómez García dedicó en 2002 a la figura de Modesto Higueras ofrece, a través del testimonio personal de este primer director del TEU Nacional, algunas fechas concretas. Según Gómez García, Modesto y Jacinto Higueras colaboraron durante el verano del 39 con el Teatro Nacional de Falange, dirigido a la sazón por Luis Escobar, quien los contrató por su experiencia previa en el teatro itinerante, puesto que ambos habían sido actores de La Barraca [2006: 32]. ${ }^{2}$ Modesto enlazó este trabajo con el encargo de constituir el Teatro Nacional de las Organizaciones Juveniles (TNOJ). La tarea se la encomendó el Delegado Nacional de dichas organizaciones, Sancho Dávila, en septiembre del 39, y su debut tuvo lugar a finales de octubre de ese mismo año, con la escenificación de un Pliego de romances españoles ordenados por Luis Rosales y Felipe Vivanco (2006: 35). Siempre según el testimonio de Higueras que nos hace llegar Gómez García, el TNOJ prolongó sus actividades durante año y medio, «con montajes clásicos [...] en realismo o estilización»

1. Debemos a mi maestro, Javier Huerta, el hallazgo de las dos principales referencias que se hacen en la prensa a este montaje del que nos ocuparemos. Agradezco desde este primer momento la generosa cesión de este dato.

2. Todas las iniciativas teatrales del nuevo régimen se remontan a 1938 (B.O.E. del 9 de noviembre), cuando el ministro monárquico Pedro Sáinz Rodríguez constituyó la Junta Nacional de Teatros y Conciertos, que daría lugar, ya en el 40, al Consejo Nacional de Teatros. 
que rodaron por «albergues, campamentos y ciudades» (2006: 34). El final de este teatro, a finales del 40 según recuerda Higueras, fue ocasionado por una sonada disputa con un delegado provincial (2006: 37). La inactividad fue breve para el director, pues Gómez García recoge que «a primeros» de 1941 recibió de José Miguel Guitarte, Jefe Nacional del SEU, el encargo de constituir la delegación nacional del TEU, que debía no solo programar montajes sino, además, asesorar a los TEUs provinciales preexistentes (2006: 43). Una vez más, fue el estro de su colaboración con Lorca en los años treinta el que justificó el fichaje de Higueras por parte de una institución cultural falangista.

La cronología de todos estos datos, como veremos, comporta no pocos problemas cuando tratamos de encajar en este relato la representación de El otro en febrero de 1940, que a) no es un montaje clásico ni itinerante, como era propio de los espectáculos del TNOJ, y que b) se promocionó como función inaugural del TEU Nacional, cuando esta tuvo lugar, según Higueras, el 23 de marzo de 1941 (2006). ${ }^{3}$ Abordaremos esta problemática en las siguientes páginas con el fin de perfilar, en última instancia, una hipótesis sobre los comienzos de esta apasionante etapa de nuestro teatro. Como telón de fondo de estas reflexiones encontraremos el interesante diálogo que los jóvenes teatreros del SEU establecieron con la obra de Miguel de Unamuno, y anotaremos la trascendencia - y la latente disidencia intelectual, tal vez- que implica la elección de El otro como primera función del TEU Nacional.

\section{Un montaje fantasma: revisión documental}

Es escasa la información de que disponemos hoy en día acerca del montaje unamuniano que nos ocupa, por esencial que este pueda resultar para la correcta indexación historiográfica del TEU Nacional dirigido por Modesto Higueras. Podemos concluir con certeza — porque así lo reflejan dos periódicos distintos- que la representación tuvo lugar ${ }^{4}$ y que se desarrolló en el Teatro Español de Madrid a las diez y media de la noche del 1 de febrero de 1940,

3. Se trata de un espectáculo del que conservamos varias noticias periodísticas y también programa de mano; incluía La mujer por fuerza, de Tirso, y Navidades en la casa Bayard, de Wilder. Se produjo en la fecha señalada, y $A B C$ avisó del mismo indicando que la había producido «el Teatro Español Universitario, totalmente reorganizado» (1941: 14) [el destacado es nuestro]. El montaje sabemos que rodó por España y volvió a la cartelera de Madrid, pues en mayo del 42 Miguel Ródenas realizó una reseña crítica de un espectáculo del TEU Nacional que incluía la obra de Wilder y El retablo de las maravillas de Cervantes (1942: 16).

4. Esta cuestión no es baladí, pues pueden documentarse algunas representaciones del TEU que fueron anunciadas, pero de las que, luego, no consta ningún dato, lo que invita a cuestionarse si verdaderamente tuvieron lugar los espectáculos. La existencia de dos 
jueves. El espectáculo tiene lugar a una hora tardía y fuera de la cartelera «oficial», que para ese mismo día anunciaba una «gala infantil» a las 16.15 -Pichi, aventurero y patriota, y Clínica de bebés-y, a las 18.30, a cargo de la compañía Guerrero-Mendoza, La santa virreina, de Pemán. ${ }^{5}$ A pesar de la atípica hora, podemos constatar que el SEU manifestó un particular interés en la promoción del montaje, pues envió el mismo anuncio a los periódicos $A B C$ ( 1 de febrero del 40) y Ya (31 de enero y 1 de febrero) para que fuera publicado en la sección dedicada a la Falange y a la Jefatura Provincial del Movimiento, respectivamente: «Hoy, a las diez y media de la noche, en el Teatro Español, la Delegación Nacional del Teatro Español Universitario, presenta el misterio en tres jornadas y un epílogo, de D. Miguel de Unamuno, El otro» (1940; 1940ab).

Al día siguiente de la representación, Juan de la Cueva y Luis Araujo-Costa publican sendas críticas del montaje en $Y a$ y $A B C$, que no ofrecen demasiados datos sobre las características del montaje. ${ }^{6}$ Araujo-Costa insiste en la naturaleza inaugural del montaje, al hablar de que «el Teatro Español Universitario del Sindicato Español universitario nace como una ramificación lozana de la FET y de las JONS», y al indicar que con esta puesta el TEU nacional «ha comenzado ayer noche sus actuaciones teatrales de cultura» (1940: 15) [los destacados son míos]. Tras aludir al estreno absoluto de la obra en el año 32, protagonizado por Margarita Xirgu y Enrique Borrás, y representado también en el Español el 14 de diciembre de aquel año, Araujo-Costa se entrega a algunas cuestiones literarias y filosóficas relativas al texto a las que aludiremos más tarde. Sobre la puesta en escena el crítico se limita a señalar que «el cuadro artístico del teatro Español Universitario presenta la obra con toda dignidad, comprensión y cariño» (Araujo-Costa, 1940: 15). Cueva, por su parte, es algo más expansivo en sus apreciaciones, a pesar de que el grueso de su reseña, una vez más, no va dirigido al montaje sino al texto. Resultó sin duda llamativa para ambos críticos la elección de Unamuno para dar comienzo a las actividades del TEU, y por ello dedican tanto espacio al autor, en detrimento de la puesta en escena. Las consideraciones de Cueva sobre la «monotonía trágica» de El

críticas de El otro el día posterior a su representación aleja esta sospecha del montaje que nos ocupa.

5. Es habitual, al menos en estos primeros años del TEU, que las representaciones, casi siempre en función única, tuvieran lugar fuera de la programación oficial, y en sesiones un tanto intempestivas (horario matinal o nocturno, o en lunes).

6. Esta es otra constante en los espectáculos del primer periodo del TEU, que gozaron de la displicencia de una crítica siempre dispuesta a aplaudir casi servilmente sus montajes. Se trata de críticas panegíricas llenas de lugares comunes, aderezadas por el leguaje épico falangista y con escasos reproches que nos llegan, si los hay, soterrados bajo la palabrería encomiástica. 
otro, sin embargo, nos han permitido saber alguna cuestión sobre el clima de la sala aquella noche, pues parece ser que la enrevesada parafernalia conceptual unamuniana hizo que la tragedia, a ratos, deviniese en carcajada:

$\mathrm{Y}$ a través de todo esto se percibe el aliento de lo grande, que algunas veces el público no llega a captar en la justa medida, como lo demostraron anoche algunas risas intempestivas que, lejos de ser inoportunas, tenían un profundo sentido y sagaz valor dramático [...] (Cueva, 1940: 3).

Como vemos, tras varias capas de retórica, el crítico nos indica que las improcedentes risotadas que se escucharon aquella noche en el patio de butacas, lejos de demostrar falta de talento de los actores, ponían en evidencia la inconsistencia trágica del drama unamuniano. Para feliz desaliento del futuro investigador del TEU, Cueva prosigue su reseña revelando que, incluso en el caso de que recuperáramos el programa de mano de esa noche, tendríamos harto difícil la tarea de encontrar más datos sobre esta representación de El otro:

Una ejemplar modestia y un alarde de trabajo entusiasta y desinteresado ha calado en programas y carteles del TEU los nombres de los intérpretes; tan digna, tan equilibrada fue su labor que quisiéramos que nuestro aplauso, unido a los que les otorgó el público, les llegara a su ejemplar anonimato (Cueva, 1940: 3).

Poco más puede añadirse a nivel documental sobre esta puesta de El otro. No hemos localizado información al respecto ni en el Museo del Teatro de Almagro, ni en el Centro Documental de la Memoria Histórica. ${ }^{7}$ El trabajo con las revistas de la época que pudieron hacerse eco de esta representación también resulta complejo, puesto que la mayoría de las colecciones de publicaciones como Arriba o Haz están incompletas y no hemos encontrado hasta el momento los relativos a febrero de 1940. Tampoco parece que el legado de Modesto Higueras pueda ofrecernos muchos más datos, aunque es conocida la necesidad de recuperar y trabajar con todo ese material, que permanece inédito en su mayoría.

Todo apunta a que fue Modesto Higueras quien se ocupó de la dirección de este montaje, en el que pudo contar, quizás, con unos pocos de los veinticinco actores del Teatro Nacional de las Organizaciones Juveniles que, hasta donde nos dice la bibliografía actual —aunque esto también debe ser necesariamente revisado- seguía funcionando por aquel entonces. La elección

7. En lo relativo a este archivo, anduvimos por algún tiempo esperanzados con un programa de mano de 1940 que se custodia entre los papeles de José Mario Armero. El documento, sin embargo, resultó ser el programa de una «velada de arte en el Teatro Victoria Eugenia que tuvo lugar el sábado 23 de abril a beneficio del S.E.U» en homenaje a José Antonio con dirección y escenografía de José Ramón de Vega y Suárez. Todo apunta a que se trata de una dramatización de los poemas de la Corona de sonetos. 
del Teatro Español como coliseo para el estreno también apunta de forma inequívoca a Higueras, cuya amistad con Felipe Lluch —director del Español desde septiembre del 39- se remontaba a los tiempos del TEA de Rivas Cherif (Gómez García, 2006: 34). Lluch, según el propio Modesto Higueras, había sido nombrado para convertir el Español en un teatro dedicado a «los clásicos nacionales en principio, y más tarde los extranjeros en refundición por autores de reconocida solvencia» (2006: 34). Al mismo tiempo, Luis Escobar había sido designado para montar en el María Guerrero a los «autores contemporáneos nacionales y extranjeros». Esta división era, como podemos suponer, meramente teórica, puesto que Pemán estaba programado para la misma tarde que El otro en un teatro que iba a estar destinado solo para los clásicos. Pensamos que fue un favor personal de Lluch a Higueras lo que permitió ampliar el programa hasta un horario inapropiado para un jueves y estrenar a Unamuno de nuevo en el Español. No es de extrañar porque, de hecho, en la segunda presentación oficial del TEU Nacional Lluch volvió a ceder el Español a la misma hora, las diez de la noche, esta vez para la famosa representación de La mujer por fuerza de Tirso, junto con la pieza corta Navidades en la casa Bayard de Wilder. Sin duda se trata, nuevamente, de un favor personal para hacer hueco al TEU al margen de la programación ya cerrada. Es plausible, aunque no hayamos comprobado aún este extremo, que la puesta de largo del Teatro Nacional de las Organizaciones Juveniles, que tuvo lugar a finales de noviembre del 39 con la dramatización de un Pliego de romances españoles compilados por Rosales y Vivanco tuviera lugar también en el Español y, quizás, en la sesión golfa de las diez de la noche, de acuerdo con esta connivencia entre Higueras y Lluch.

\section{Nueva cronología de los orígenes del TEU Nacional: hipótesis proyectiva}

Resulta curioso que sea «la Delegación Nacional del Teatro Español Universitario» la que se proclame productora de este montaje de Unamuno, puesto que, de acuerdo con la bibliografía que existe hasta la fecha, dicha Delegación per se no existía en 1940, por lo que debemos revisar toda la historiografía de los orígenes del TEU y, más concretamente, la biografía del propio Modesto Higueras. Para afrontar esta tarea es imprescindible asumir una consustancial dificultad relativa a la inconsistencia de las fechas -errores en los programas, representaciones fantasma que nunca llegaron a realizarse, la mala memoria del propio Higueras en sus inconclusas memorias-, y a la punzante falta de documentación. A pesar de todo esto, al rastrear las huellas de la representación universitaria de El otro en el 40 me he topado con algunas contradicciones sugerentes, y algunos datos que acreditan la extraordinaria vitalidad de que el TEU —o, más bien, los pequeños TEUs de cada 
universidad- gozó antes de su oficialización a través, primero, del Teatro Nacional de las Organizaciones Juveniles y, después, de la Delegación Nacional creada por Guitarte.

La primera cuestión, ya conocida aunque poco atendida hasta el momento, afecta directamente a la cronología de los orígenes del TEU, que no empieza ni mucho menos en el 39 con Modesto Higueras: existieron diversos corpúsculos teatrales universitarios pre-existentes al encargo que Sancho Dávila le hizo a Higueras en septiembre del 39, e incluso anteriores al final de la contienda civil. Reseñaré brevemente algunas de estas experiencias anteriores a lo que el propio Higueras considera, según Manuel Gómez García, el debut del TEU en octubre del 39. Por motivos de concreción, y para no cansar a los desocupados lectores, me limitaré a los datos que aporta la sección teatral del periódico $A B C$ :

A. 04.08.1938 (ABC Sevilla). Se anuncia «un festival en beneficio de la Macarena» a cargo del Teatro Español Universitario del SEU en el que «se representará por primera vez en Sevilla un auto sacramental al aire libre». El día $7 A B C$ vuelve a referir el acontecimiento, añadiendo que el montaje ha sido sufragado por Queipo de Llano y que se llevará a cabo «en el parque de María Luisa».8

B. 19.01.1939 (ABC Sevilla). En el punto segundo del orden del día de la reunión del SEU publicado en este periódico se consigna una interesante admonición: «se ordena a todas las camaradas que durante el año 1938 han tomado parte en las clases de Gimnasia Rítmica, Orfeón y Teatro Español Universitario, se presenten en nuestro local de doña María Coronel [...] para asunto de gran interés». Parece que el «asunto» cultural solo competía a las camaradas de sexo femenino, lo que resulta muy interesante de cara a trazar, en el futuro, una historia de las mujeres del TEU.

C. 13.07.1939 ( $A B C$ Madrid). Se relata que, con motivo de la visita del Buque Escuela Argentina, el TEU de Cádiz estrenará El médico de su honra en el Gran Teatro Falla —nuevamente vemos la recurrencia de poner los grandes teatros públicos al servicio del SEU-, en una función de gala «el viernes por la noche»—es decir, nuevamente fuera de la programación oficial-.

D. 23.07.1939 ( $A B C$ Madrid), con motivo de las «tradicionales fiestas de Santiago Apóstol» tuvo lugar el día 25 de julio, a las seis, «la

8. Para conocer todos los pormenores de la cartelera andaluza del TEU es imprescindible el reciente estudio de $\mathrm{M}^{\mathrm{a}}$ Jesús Bajo Martínez, en el que son analizados todos los montajes similares a este del 38 (2016). 
presentación de las Organizaciones Juveniles de Alcalá, del Guiñol del Teatro Español Universitario de Madrid». Parece, por lo que nos indica este recorte, que el TEU provincial de Madrid funcionaba a través de la sección provincial de las Organizaciones Juveniles, y que el encargo de Dávila a Higueras se refiere a la creación de un Teatro Nacional para todas estas Organizaciones particulares, y no para la creación de un TEU en Madrid que, como vemos, ya existía.

E. 11.08.1939 (ABC Madrid). Encontramos una nueva referencia al «Guiñol del Teatro Español Universitario». En este caso, se indica que pertenece al SEU de Magisterio de Madrid, lo que apunta aún a una mayor atomización del TEU madrileño por Facultades. Estrenaron «en la terraza de la Escuela Normal» la obra falangista Periquito contra el monstruo de la democracia, de Alejandro Blas y Agustín Embuena. Antes tuvo lugar un discurso que, según Araujo-Costa, «merece las más cumplidas alabanzas, por la obra pedagógica que han de realizar en nuestro país, con una forma perfectamente legítima de teatro y sirviendo las ideas que han triunfado en el glorioso Movimiento Nacional» (1939: 19). La recurrencia de estas noticias sobre el Guiñol del TEU de Alcalá apunta a que gozó de cierta fama en estos primeros años y a que tuvo una importante acogida popular. ${ }^{9}$

F. 16.08.1939 ( $A B C$ Madrid). Se reporta la «adjudicación de premios en un certamen de música», y se nos dice que «una de las obras premiadas, Tupido velo, será interpretada musical y coreográficamente por la Sección de Música y Danzas del Teatro Español Universitario». Esta noticia apunta a que existía una estructura compleja en algunos de estos corpúsculos, con secciones específicas para teatro, danza, etc.

Así las cosas, parece que el encargo de Guitarte a Higueras para organizar un TEU Nacional no se produjo tanto con el objetivo de fundar una praxis teatral universitaria, sino de poner orden o estructurar la multiplicidad de prácticas que en toda España se venían realizando desde tiempos de la II República. Esta práctica teatral previa al año 41 en la que se inscribe el montaje de El otro al que nos referimos pone en tela de juicio el testimonio indirecto y memorístico que conservamos de Modesto Higueras. Si el estreno de El otro se publicitó como primera función de la Delegación Nacional un año antes de ese pretendido debut, nos encontramos, pues, ante una doble presentación del TEU

9. En mayo del 40 la revista del SEU, Haz, nos ofrece una nueva noticia sobre este teatro de títeres, que se trasladó a El Pardo para hacer una representación ante Carmen Franco y sus primos, que luego pasearon con los titiriteros por los jardines del palacio. 
Nacional. Es significativo que la prensa del año 41 nunca hable de una función inaugural cuando presenta el montaje de La mujer por fuerza y Navidades en la casa Bayard, sino de un TEU «completamente reformado», por lo que es probable que debamos considerar que solo El otro supuso la puesta de largo del TEU Nacional.

Sobre la presencia de Modesto Higueras en este primer momento del TEU conservamos un documento de1960 que contradice lo indicado por Gómez García. En un curso impartido en Santander y organizado por el Teatro del SEU de esta ciudad impartió Modesto Higueras la conferencia inaugural. Con el programa que anuncia la ponencia se entrega una breve semblanza del director, donde se señala que «en octubre del 39 funda y dirige el Teatro Nacional de las Antiguas Organizaciones juveniles» (1960). Esto cuadra con los datos que tenemos hasta la fecha, pero a renglón seguido se dice que «en enero de 1940» crea el TEU Nacional por orden de José María Guitarte y asesora los otros», lo cual es coherente con el hecho de que el El otro sea la función inaugural del TEU Nacional, pero consistente con el estreno, también fundacional, de 1941.

De ser cierto lo que se dice en esta separata de la conferencia, tendríamos que aceptar que el Teatro Nacional de las Organizaciones Juveniles tuvo un recorrido verdaderamente corto (de octubre a diciembre del 39), o que de alguna forma inexplicada ambas estructuras conviven, se confunden o solapan durante el año 40, lo cual sigue sin explicar el carácter de la «segunda inauguración» del TEU en el 41. Desde luego, el carácter contemporáneo de El otro desentona con el repertorio del Teatro de las Organizaciones Juveniles, que es clásico. Por tanto, solo consideramos aceptables dos hipótesis: o existió una dirección nacional del TEU anterior a Higueras que pueda explicar que $A B C$ hable de un Teatro Español Universitario «totalmente reformado», lo cual es improbable - porque, de ser así, estaría documentada alguna clase de referencia al anónimo director-, o el estreno del 40 no tuvo el éxito o el eco esperado - por la hora intempestiva, por el texto, por las prisas con que hubo de montarse-y se prefirió hacer, un año después, una segunda puesta de largo que sin duda ha tenido mucha mayor trascendencia. ${ }^{10}$ Esta es sin duda mi

10. Ambas probabilidades son, por supuesto, combinables; es decir, es posible que un primitivo director del TEU Nacional fracasara con sus intentos del año 40 y eso llevara a Guitarte a reformar completamente la estructura de la compañía, encargándosela a un director de acreditada pericia en el terreno del teatro universitario como era el caso de Modesto Higueras. ¿Podría ser el misterioso José Ramón de Vega y Suárez, que dirigió el homenaje joseantoniano de mayo del 40, el primer director de la primitiva delegación nacional del TEU? El programa de mano que se conserva entre los papeles de Armero es el único apoyo documental que en este momento podría apoyar indirectamente esta opción. 
hipótesis actual, que nos lleva en cualquier caso a un cambio historiográfico sustancial: es muy probable que Modesto Higueras iniciase su recorrido en el TEU Nacional con un montaje de Unamuno, El otro.

\section{El nexo de Unamuno con el TEU y la recepción de sus ideas teatrales en Falange}

La pregunta que surge inmediatamente tras haber alcanzado esta conclusión provisional es por qué elegiría Modesto Higueras a Unamuno para esta primera representación. En este caso creo que la razón nuevamente tiene mucho que ver con las afinidades personales y la amistad y la nostalgia, que como acabamos de ver en el caso de Lluch, contaba mucho para los directores del TEU. Así, Modesto Higueras decidió inaugurar el TEU Nacional con un sentido homenaje a uno de los mayores admiradores con los que contó La Barraca: don Miguel de Unamuno. Cuenta Modesto que don Miguel, de quien sabemos que no solía ir al teatro porque prefería la lectura del teatro a la puesta en escena (Salas 2007), solía viajar a cualquier pueblo donde fuera La Barraca para ver una y otra vez los montajes, a través de los cuales trabó una cariñosa amistad con Federico y con el propio Modesto:

En el famoso café palentino situado en la calle Mayor de Palencia —refiere Modesto- estábamos tomando un café Lorca, Unamuno y yo. Don Miguel era lo que actualmente se dice fan de un artista o de un espectáculo; pues bien, don Miguel era un fan de La Barraca y admiraba mucho a Lorca; estaba en la ciudad para ver por tercera vez El burlador de Sevilla y convidado de piedra, de Tirso, que era una de las obras más ejemplares y bien montadas. A una pregunta algo copiosa e impulsiva propia de mis benditos años, me respondió: «Mira, jovencito: en este país nadie se muere de hambre. Quizá en la India. De lo que suele morirse aquí la gente es de asco (Gómez García, 2006: 30).

Esto significa que Higueras realizó en 1940 una fuerte declaración de intenciones al montar El otro: por un lado, tributar homenaje a un viejo admirador del espíritu universitario de La Barraca — un autor, por cierto, visto durante los cuarenta con ciertas reticencias por una parte del oficialismo-y, por otro, establecer una filiación nítida entre el magisterio de García Lorca y su labor como director teatral.

Higueras mantuvo su reconocimiento a Unamuno aun cuando todo apunta a que el estreno de El otro no le procuró el éxito esperado. Prueba de esta devoción es que incluyera al autor dentro del ciclo sobre autores teatrales contemporáneos que organizó entre enero y julio del 67 en RNE, en el programa «Historia esquemática del Teatro español». En cada una de las sesiones de este ciclo se impartía una conferencia y se desarrollaba una presentación del autor 
correspondiente, que iba acompañada de una representación radiofónica «de la escena fundamental de la obra comentada» (Gómez García, 2006: 78). No sería descabellado pensar que Higueras escogiera una escena de El otro para el programa dedicado a Unamuno. ${ }^{11}$

No es este lugar para recuperar por enésima vez los variados testimonios que desarrolló la Intelligentsia falangista para apropiarse de la figura y el legado de Unamuno y, en general, de todos los autores del 98, en quienes la Falange ve un claro precedente de su posición cultural y cívica con respecto a la regeneración de España. Ya en los años treinta Giménez Caballero, en Genio de España, se había declarado «nieto del 98» (1983: 17-22), compromiso suscrito con mayor rigor intelectual por Laín Entralgo en varias obras, entre las que destacamos La generación de 1898, donde califica de «irracionalismo espiritualista o espiritualismo irracional» el pensamiento «oscuro» de Unamuno (1975: 151-152). ${ }^{12}$ En España como problema Laín Entralgo acoge con mayor entusiasmo la oportunidad de declararse, como Giménez Caballero, Nieto del Noventayocho, y sitúa en su diálogo con Unamuno una de sus principales líneas de reflexión sobre España:

En la lucidez espiritual de la creación y del ofrecimiento radica la sal de Europa; y así, cuando hay europeos turbios, como Nietzsche y Unamuno, debe haber sin demora europeos claros, capaces de elucidar la verdad yacente en el seno de la turbidez, y luego europeos sobreclaros, dignos de ofrecerla a Dios (2005: 399).

Nuevamente, tras la reticencia inicial —Unamuno es turbio, y se le equipara nada menos con Nietzsche, paroxismo del irracionalismo y del descreimientose indica que en «el seno de la turbidez» late una verdad honda que otros espíritus más racionalistas —entendemos que se incluye Laín entre ellosdeben «elucidar». A esta tarea de recuperación ideológica contribuyó en buena medida la hasta hoy confusa relación de Unamuno con el falangismo, pues el pensador, que había espetado a un antiguo alumno, ahora falangista, que dejara de vestir como un mamarracho, terminó sus días en olor de santidad

11. Unamuno siguió teniendo una cierta presencia en el TEU. El otro se volvió a representar el 27 de marzo de 1960 por el TEU de Ingenieros Industriales de Madrid, con dirección de José Luis de Zumárraga y «efectos especiales» de un jovencísimo Javier Krahe. Consta también, en el 64, una puesta de El tiempo que vuelve (Castilla, 1999: 247).

12. Es una constante en toda la exégesis que se hizo de Unamuno en la posguerra acompañar el elogio y la apropiación hermenéutica de su pensamiento desde el imaginario falangista, de calificativos peyorativos o apreciaciones que aminoran el valor de su disidente iconoclastia. Es típico, en este sentido, que se hable de su «peculiar» o «particular» forma de entender cualquier cuestión, o que se señalen su oscuridad, su irracionalismo o sus contradicciones como elementos constitutivos de su filosofía. 
nacional sindicalista. En su entierro, el féretro fue llevado a hombros por el tenor Miguel Fleta y Víctor de la Serna, y Unamuno fue despedido, según cuenta este último en la revista Alcázar, al grito de «iPresente!» (Serna, 1986). En fin, una compleja relación con la Falange ya muy estudiada y perfectamente reflejada en el espléndido artículo de Mercedes Tasende (2007).

En cualquier caso, y aunque sería falso afirmar que Unamuno fue una figura proscrita en el franquismo, sí es destacable que su nombre es poco mencionado en los primeros años cuarenta. Cuando se le cita, es de forma indirecta y no en estudios monográficos sobre él, y siempre para hacer alguna matización a su pensamiento, aludir a la ingenuidad de su actitud filosófica o, en suma, marcar distancia con el maestro. Así sucede, por ejemplo, en el segundo número de Escorial, donde Ridruejo reconoce, con pocas concesiones el ansia reformadora de Unamuno:

Del estamento universitario, solo la voz atormentada, profunda e incoherente de Unamuno clamó en este siglo con ansias de tal género; y si ciertamente se le consideró español, también es cierto que se le tuvo por loco (1940: 178).

En términos muy similares se pronuncian los críticos de El otro estrenado por el TEU en 1940, en quienes encontramos la misma actitud admirativa pero matizada. Araujo-Costa, que valora la obra como exponente del sentido trágico de la vida defendido por Unamuno, considera al filósofo «siempre gran señor del mundo de las ideas y uno de los que contribuyó, no obstante algunos errores, a realzar en España la vida del espíritu» (1940: 15) [el desatacado es mío]. Juan de la Cueva no adopta un juicio tan moral y se limita a constatar como la preponderancia tiránica del conflicto sobre el resto del acto escénico termina devorando los ambientes, los caracteres, los tipos, etc. Unamuno «agiganta artificialmente» la obsesión que da origen a su núcleo de convicción dramática, «buscando, acaso más que hacerlo interesante, convertirlo en una obsesión para el público también» (Cueva, 1940: 3). Como vemos, Unamuno no es, ni mucho menos, una figura mal vista, pero en estos primeros años quizás sí es contemplada con alguna cautela por algunos sectores. Pongamos otro ejemplo. En el año 41 Escorial publica un exhaustivo artículo de Julián Marías sobre «El problema de Dios en la filosofía de nuestro tiempo», un completísimo ensayo que va de Platón hasta Ortega y Zubiri, pero en el que el nombre de Unamuno, figura tan principal en lo relativo al estudio del problema de Dios en nuestro país — desde luego figura más señera en este terreno que Ortega—, ni siquiera es mencionado.

Cosa muy otra sucede con las ideas teatrales del dramaturgo, sobre las que unos y otros debaten desde pronto con el común acuerdo de un rechazo a su producción teatral, considerada siempre inferior al resto de su obra literaria 
y ensayística, y en cuyo fracaso se suele insistir machaconamente. Torrente Ballester publicó en el décimo número de Escorial (1941) un interesantísimo ensayo titulado «Cincuenta años de teatro español y algunas cosas» donde enumera algunos problemas del teatro de Unamuno, aunque da preponderancia a su exceso de intelectualidad:

[...] en el de Unamuno, por falta de «oficio», y por exceso de profundidad — por plantear, como se decía entonces, «problemas de intelectuales, problema sin humanidad»-; y es los demás, por parecidas razones. De lo que se infiere que, el si teatro representado careció de gravedad y peso, el que se limitó al libro o a la representación eventual no pudo imponer su influencia ni sobre el público ni sobre los restantes dramaturgos (1941: 278).

En 1953 Mariano Rodríguez de Rivas trató de reivindicar el teatro de Unamuno en un largo artículo publicado en el número 71 de Correo literario, aunque desde luego con mala estrategia, porque el trabajo incluye un subtítulo nada reivindicativo: «Su teatro no interesó a los espectadores». Las líneas de Rodríguez de Rivas, que tratan de convertirse en un elogio de la Fedra unamuniana, principian repitiendo una y otra vez el estrepitoso fracaso del teatro del autor, pues productores y directores rechazaron poner en pie sus textos, con la significativa excepción de la Xirgu y Borrás en el caso de El Otro en 1932 (1953: 8-9).

Detectamos mayor sintonía con las ideas teatrales de Unamuno en un artículo anónimo publicado en Haz a principios del año 40, posiblemente escrito por Bernardo Simonet (1914-1995), escenógrafo del TEU. ${ }^{13}$ El texto, titulado «Escenografía de carne y hueso», asume la necesidad de una escenografía arquitectónica y orgánica, en la línea de Appia, Craig o los grandes escenógrafos de las óperas de Wagner: «Un decorado auténtico para nosotros es aquel que logra resaltar en su unidad un organismo dramático que en la decoración encuentra su valor» (Simonet, 1940: 82). Pero esta organicidad es entendida desde una perspectiva unamuniana, porque siempre se da prioridad al texto sobre lo escénico, pidiendo que el aditamento escénico se ponga al servicio del texto sin alejarnos de él ni desdibujarlo del centro del acto teatral:

La escenografía que le dé sentido [al nuevo modo de representar a los clásicos] sea una escenografía que nos entregue su radical elocuencia, y que al ser eco

13. El artículo viene acompañado de cuatro escenografías de este escenógrafo, hijo y discípulo del también pintor Enrique Simonet (1866-1927). Todas estas escenografías —el Fausto de Goethe, Don Juan Tenorio, La antorcha encendida, de D'Annunzio y otra obra no mencionada - se indica que han sido diseñadas «para el TEU», y todas ellas tienen en común la elegancia y el aspecto colosal — propio del teatro de Appia o Gordon Craig-y, de facto, recuerdan a los dibujos de Miquel Xirgu para la Fedra de Unamuno. Dado que el artículo versa sobre escenografía, lo más sensato es pensar que el autor del mismo es el propio autor de las litografías que lo acompañan.

Anales, 29-30 (2018), pp. 47-63 
justo de la acción teatral, se olvida de toda esa "guardarropía» escénica que no es sino pura resonancia, tosca aproximación o un exceso decorativo capaz de desvalorizar la esencia dramática de lo que se representa (Simonet, 1940: 84).

Nótese que el concepto de «guardarropía» es equivalente al de perifollo que Unamuno solía emplear para hablar del exceso de ornamentación en el teatro. Frente a la tradicional escenografía de telón pintado y bastidor, Simonet indica, como Unamuno, la necesidad de una escenografía arquitectónica. Por eso se habla de una «escenografía antiteatral», muy en la línea del rechazo de Unamuno por el concepto decimonónico de lo teatral y en sintonía con su propuesta de renovación purista.

\section{¿Una relectura falangista de El otro?}

Finalizaremos, después de estas reflexiones sobre la presencia de Unamuno en el imaginario falangista, con un breve apunte sobre cómo pudo ser la lectura que los espectadores falangistas de El otro en 1940. Tras la elección de El otro como primera obra del TEU Nacional no solo laten las filias personales de Modesto Higueras hacia el autor o la necesidad espiritual de vincular su empresa con la lorquiana, sino otros resortes que, incluso de modo contradictorio, articulan el diálogo entre la introducción de una veta disidente - porque Modesto no es falangista y así se lo dice a Dávila al dimitir-y la plena aceptación del discurso dramático por parte de los falangistas del SEU.

En el primer sentido es necesario encuadrar correctamente la audacia que suponía en la primera posguerra poner cualquier obra asociada con la guerra entre hermanos. La presencia del mito de Antígona es, por ejemplo, francamente impresionante: a las versiones de Sófocles y Anouilh estrenadas por parte del TEU murciano, debemos sumar con pleno derecho la excepcional Antígona de Salvador Espriu, construida con plena conciencia de la latencia del guerracivilismo. Lo mismo sucede con el mito de Caín y Abel, muy querido de Unamuno y abordado desde una perspectiva intelectual en El otro, pero no por ello menos cruda ni llamativa para un pueblo cuyo desgarro seguía vivo en la memoria colectiva del público. La propia onomatología de los personajes de El otro, teñida de una fina ironía hagiográfica por parte de Unamuno, pone sobre la mesa de la posguerra la oscilación entre la destrucción de los hermanos - Caín y Abel- y la reconciliación y la convivencia pacífica entre ellos, a través de la figura de los gemelos san Cosme y san Damián, que vivieron y padecieron martirio de forma conjunta, y siempre juntos son honrados por la Iglesia. Cierto es que el impulso unamuniano es netamente intelectivo — «la obsesión [...] de la personalidad, del sentimiento congojoso de nuestra identidad» (Martín 2007: 117)—, pero las concomitancias que el espectador podía encontrar con 
la situación que acababa de vivir el país serían prístinas, por más que la obra no censure ni condene de forma explícita la lucha fratricida.

¿Por qué no se prohibió, pues, una obra que denuncia las horribles consecuencias de los conflictos entre hermanos? La respuesta es bastante más sencilla que las que hemos intentado ofrecer para las demás dudas que hemos planteado en este trabajo. En el lado de la Falange, y aunque Unamuno no era un personaje elogiado sin fisuras, El otro se limita a exponer, en cierto sentido, la inevitabilidad del asesinato del hermano. No encontramos, en el intelectualismo con que Unamuno aborda el cainismo en El otro, una censura, sino una trágica constatación de que los hermanos estaban condenados a matarse y que el vencido - Abel - es también un fratricida en potencia:

OTRo. -¡Caín! ¡Caín! ¡Caín! Me lo digo yo a mí mismo todas las noches, en sueños, y por eso duermo solo, encerrado y lejos de todos. ¡Para que no me oigan..., para que no me oiga yo a mí mismo!... ¡Pobre Caín! ¡Pobre Caín! Pero también me digo que si Caín no hubiera dado muerte a Abel, Abel habría matado a Caín... ¡Era fatal! Ya de chicos, en la escuela, era broma preguntarle a otro de sopetón: «¿Quién mató a Caín?» Y el preguntado solía caer y replicaba: «Su hermano Abel». Y así fue. Y en todo caso, ¿se es Caín por haber matado al hermano, o se le mata por ser Caín? (Unamuno, 1969: 25-26) [el destacado es mío].

Es probable que en este expediente trágico de los dos hermanos condenados a ser el otro, es decir, a pelearse y triunfar de su contrario, el SEU viera una legitimación de la inevitable Cruzada del Caudillo. Hoy sabemos que Higueras, al montarlo, dejaba respirar en los escenarios españoles un emocionado tributo al genial pensador, pero también a García Lorca, su maestro: dos intelectuales de los tiempos de la República subidos a las tablas del Movimiento.

\section{Bibliografía citada}

ANÓNIMO, «Un festival a beneficio de la Macarena», ABC, 4 de agosto de 1938.

—, «Patrocinada por el Excmo. Sr. General Queipo de Llano...», ABC, 7 de agosto de 1938.

-, «Falange Española Tradicionalista y de las J.O.N.S. Sindicato Español Universitario», ABC, 19 de enero de 1939.

—, «Las tradicionales fiestas del Apóstol Santiago. Los actos que celebrará el S.E.U de Madrid en Alcalá de Henares», ABC, 23 de julio de 1939a.

—, «Falange Española Tradicionalista y de las J.O.N.S. Lope de vega en el Real Monasterio de san Lorenzo de El Escorial», ABC, 23 de julio de 1939b.

—, «Teatro Español Universitario», Ya, 31 de enero de 1940

—, «Teatro Español Universitario», Ya, 1 de febrero de 1940a

—, «Teatro Español Universitario», ABC, 1 de febrero de 1940b. 
—, «Guiñol del SEU en El Pardo», Haz, mayo de 1940.

—, «Actuación del Teatro Español Universitario», ABC, 23 de marzo de 1941.

—, «Teatro de sátira y humor español y notas sobre la realización escénica» [invitación a conferencia de Modesto Higueras], Servicio de Teatro del S.E.U de Santander, 1960.

ARAUjo-Costa, L., «El guiñol del Teatro Español Universitario», ABC, 11 de agosto de 1939, p.19.

—, «Español: una representación de El otro», ABC, 2 de febrero de 1940, p. 15.

BAjo MARTínez, M. J., El teatro universitario en Sevilla, 1940-1990 (tesis doctoral inédita). Sevilla, Universidad de Sevilla, 2016.

BAllester, T., «Cincuenta años de teatro español y algunas cosas», Escorial, 10 (1941), pp. 253-278.

Castilla, A., «Diez años de teatro universitario en España y en América (19581968)», en Luciano García Lorenzo (ed.), Aproximación al Teatro Español Universitario (TEU), Madrid, CSIC, 1999, pp. 235-278.

CIFRA (EFE), «La visita a España del buque escuela "Argentina". Agasajos en honor de los marinos argentinos», $A B C, 13$ de julio de 1939, p.15.

-, «Adjudicación de premios en un certamen de música», $A B C, 16$ de agosto de 1939, p. 16.

Cueva, J. de la, «El otro, drama de don Miguel de Unamuno», Ya, 2 de febrero de 1940, p. 3.

Gómez Corredera, P., «Unamuno dramaturgo: un traje escénico para un teatro desnudo», Cuadernos de la Cátedra Miguel de Unamuno, 41 (2006), pp. 23-34.

GÓmez García, M., Un hombre de teatro. Modesto Higueras. El Maestro y la Asamblea, Madrid, Gráficas Caro, 2006.

GimÉnez Caballero, E. [1932], Genio de España. Exaltaciones a una resurrección nacional y del mundo, Barcelona, Planeta, 1983.

LAÍN ENTRALGO, P. [1945], La generación del noventa y ocho, Madrid, Espasa-Calpe, 1975.

—, [1956], España como problema II. Desde la generación del 98 hasta 1936, Barcelona, Galaxia Gutenberg, 2005.

LÁzaro Carreter, F., «El teatro de Unamuno», Cuadernos de la Cátedra Miguel de Unamuno, 7 (1956), pp. 5-29.

MARÍAS, J., «El problema de Dios en la filosofía de nuestro tiempo», Escorial, 2 (1941), pp. 433-461.

MARTín R., «"El que se enterró": germen de El otro, o el misterio del doble de Unamuno», Cuadernos de la Cátedra Miguel de Unamuno, 44 (2007), pp. 113-124.

Oliva, C., «La escena universitaria española», en Luciano García Lorenzo (ed.), Aproximación al Teatro Español Universitario (TEU), Madrid, CSIC, 1999, pp. 15-30. 
PÉREZ-Resilla, E., «La situación del teatro universitario en España desde 1939 a 1967», en Luciano García Lorenzo (ed.), Aproximación al Teatro Español Universitario (TEU), Madrid, CSIC, 1999, pp. 31-53.

RIDRUEJO, D., «Editorial», Escorial, 2 (1940).

Robertson, D. G., «Unas notas sobre el teatro de Unamuno», Cuadernos de la Cátedra Miguel de Unamuno, 27-28 (1982), pp. 175-179.

RÓDENAS, M., «El teatro Español Universitario presentó anoche en el Español un espectáculo de alta categoría», ABC, 7 de mayo de 1942.

RodríGUEZ DE Rivas, M., «La experiencia teatral de don Miguel de Unamuno», Correo literario, IV.71 (1953), pp. 8-9.

SALAS, T., «Unamuno y Ortega: una pequeña polémica sobre teatro», Espéculo: Revista de Estudios Literarios, 36 (2007); < http://www.ucm.es/info/especulo/ numero36/unamorte.html > [consulta: 10 de diciembre 2017].

SERnA, V. de la, «Rito falangista en la muerte de Unamuno», El Alcázar, 31 de diciembre de 1986.

¿Simonet, B.?, «Escenografía de carne y hueso», Haz. Semanario deportivo universitario, número extraordinario de principios de 1940, 80-85.

Unamuno, M., El otro. Hermano Juan, Madrid, Espasa-Calpe, 1969.

TASENDE, M., «¿Unamuno fascista?: la paradójica relación entre Miguel de Unamuno y los falangistas», España contemporánea: Revista de literatura y cultura, 20.2 (2007), pp. 49-76. 